\title{
Participatory Development of Ergonomic Design-for-Fixture Guidelines: A Case Study
}

\author{
Judy Village
}

Ryerson University

\section{Tim Annett}

Ryerson University

Michael Greig

Ryerson University

\section{W. Patrick Neumann}

Ryerson University

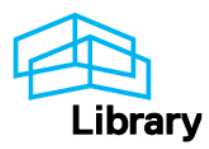




\title{
PARTICIPATORY DEVELOPMENT OF ERGONOMIC DESIGN-FOR-FIXTURE GUIDELINES - A CASE STUDY
}

\author{
Judy Village, Tim Annett, Michael Greig, W. Patrick Neumann
}

\author{
Human Factors \& Engineering Lab, Department of Mechanical and Industrial Engineering, Ryerson University \\ Research in Motion, Waterloo, Ontario
}

Human factors, design guidelines, assembly ergonomics

\begin{abstract}
This paper describes one initiative in a 3 year-collaboration between Research In Motion (RIM) and Ryerson University, the goal of which is to integrate human factors (HF) considerations into the process of designing assembly systems. The RIM-Ryerson steering group suggested this initiative because the engineering group was formalizing their fixture development process with the goal of improving the quality and timeline for fixture design. To incorporate HF into design, research has suggested that the combination of a few specific HF design criteria and active involvement of HF specialists are both critical for positive outcomes. In this initiative, Ergonomists analyzed current assembly fixtures for ergonomics-related concerns. These were shared with nine design engineers in a workshop with a goal of translating the concerns into design guidelines that would prevent the concern. The workshop resulted in 12 design guidelines that are now ergonomic requirements for internal or external vendors. The new fixture development process now includes four process stages where the Ergonomist, working proactively as a design team member, ensures the design meets ergonomics requirements. The stages are: fixture design kick-off meeting to clarify design requirements and initiate the DFMEA (design failure modes effects analysis); the fixture design review; the production tool design sign-off; and lessons learned. The combination of ergonomic design-for-fixture guidelines and the participation of Ergonomists in the fixture design process have the potential for improving assembly ergonomics and quality across thousands of workers.
\end{abstract}

\section{DÉVELOPPEMENT PARTICIPATIF DE LIGNES DIRECTRICES POUR LA CONCEPTION ERGONOMIQUE DE DISPOSITIFS DE FIXATION : UNE ÉTUDE DE CAS}

\section{RÉSUMÉ}

Le présent article décrit une initiative de collaboration d'une durée de trois ans entre Research In Motion (RIM) et l'Université Ryerson, dont l'objectif vise à intégrer les facteurs humains (HF) dans le processus de conception de systèmes d'assemblage. Le groupe directeur RIM-Ryerson avait proposé cette initiative parce que le groupe d'ingénierie voulait formaliser son processus de développement de dispositifs de fixation dans le but d'améliorer la qualité et l'échéancier de la conception de ces dispositifs. Afin d'intégrer les FH dans la conception, la recherche indique qu'il est indispensable de combiner certains critères d'ergonomie spécifiques à la conception et de solliciter une participation active de spécialistes en ergonomie pour l'obtention de résultats positifs. Dans le cadre de cette initiative, des ergonomes ont analysé l'assemblage actuel de dispositifs de fixation afin de déceler les préoccupations liées à l'ergonomie. Ces préoccupations ont ensuite été partagées avec neuf ingénieurs, dans le cadre d'un atelier, et se sont traduites par des lignes directrices de conception afin de prévenir les problèmes. L'atelier a donné lieu à 12 lignes directrices de conception qui font maintenant partie des exigences ergonomiques pour les fournisseurs internes ou externes. Le nouveau processus de développement de dispositifs de fixation comprend maintenant quatre étapes au cours desquelles l'ergonome, travaillant de façon proactive avec les membres de l'équipe de conception, veille à ce que celles-ci répondent aux exigences ergonomiques. Ces étapes sont : la réunion de lancement de la conception des dispositifs de fixation afin de clarifier les exigences de conception et d'amorcer l'analyse des modes de défaillance et de leurs effets (FMEA); l'examen de la conception des dispositifs, l'autorisation pour la conception de l'outil de production; et les leçons tirées. Le fait de combiner des recommandations de conception pour les dispositifs de fixation et la participation d'ergonomes au processus de conception des dispositifs offrent la possibilité d'améliorer l'ergonomie d'assemblage et la qualité pour des milliers de travailleurs.

Mots clés : facteurs humains, lignes directrices de conception, ergonomie d'assemblage 


\title{
PARTICIPATORY DEVELOPMENT OF ERGONOMIC DESIGN-FOR-FIXTURE GUIDELINES - A CASE STUDY
}

\author{
Judy Village, Tim Annett, Michael Greig, W. Patrick Neumann
}

\begin{abstract}
Human Factors \& Engineering Lab, Department of Mechanical and Industrial Engineering, Ryerson University Research in Motion, Waterloo, Ontario
\end{abstract}

Human factors, design guidelines, assembly ergonomics

\section{DESCRIPTION OF THE PROBLEM}

Research in Motion (RIM) and the Human Factors Engineering Lab at Ryerson University are collaborating on a 3-year project, the goal of which is to integrate human factors (HF) considerations early in design of assembly production lines. This paper will discuss one initiative - development of ergonomic design-for-fixture guidelines and implementation of guidelines and Ergonomists in the fixture design process.

It is widely suggested that HF should be incorporated into design processes to have greater decision latitude regarding prevention of HF concerns (Skepper et al., 2000; Jensen, 2002; Neumann, et al., 2009). Researchers suggest that the combination of a few specific criteria and active involvement of HF specialists are both critical for positive outcomes (Munck Ulfsfalt et al., 2003; Wulff et al., 1997; Jensen, 2002). Further Broberg (2007) suggests that a collaborative design process that involves different occupational groups facilitates good HF design. This initiative addresses the need for both HF design criteria, and a design process integrating the HF specialist. Design process is defined as the systematic series of actions undertaken to design a product, a system or a project (Skepper et al., 2000).

A fixture is a device used to secure a work piece, generally while a machine or tool performs an assembly task. In this context, fixtures can be the size of a deck of playing-cards, or as large as a computer monitor. Fixtures operate at the interface of workers and assembly tasks. Therefore, the design of fixtures can influence the forces, postures, and ease of assembly, which in turn influence production speed and quality. Fixtures at RIM are part of every assembly workstation. They may be designed and built in-house, or by an outside vendor. Incorporating ergonomic guidelines into design of fixtures can therefore influence thousands of workers worldwide who assemble RIM products.

\section{INTERVENTION \& METHODS}

In 2011, coincident with the RIM-Ryerson collaboration, the engineering group was formalizing their fixture development process. The goal was to improve the quality and timeline for design of fixtures. The steering group of the RIM-Ryerson collaboration saw this as an opportunity to incorporate HF into both the design guidelines and the design process.

It was important for the Ergonomists to understand the various stages of the fixture design process to advise where best an ergonomic review should be incorporated. Through meetings with engineers, Ergonomists were guided through the process steps during fixture design for a new assembly. At the early requirements stage in the new process, Engineers (internal and external) would be required to refer to design for fixture guidelines. The first draft of these guidelines contained 24 items, one of which referred generally to whether "ergonomic requirements have been addressed". Since the requirement was non-specific and Engineers may not know when they had succeeded in meeting these requirements, the Ergonomists set a goal to provide improved and more specific guidelines.

The Ergonomists performed a series of ergonomic assessments of fixtures currently on the assembly line, and discussed concerns with workers. A list of 28 concerns resulted. The challenge was then to determine how to translate an "ergonomic concern" into a "design guideline" in such a way that engineers would understand and address the concern. For example, one concern observed was sustained forward neck flexion required when using some fixtures. The neck flexion is a result of visual requirements, both of the fixture as well as the angle of attachment of the part. A guideline suggesting neck flexion should be minimized is not useful for a fixture design engineer, since their focus is primarily on the function and performance of the actual device - not the operator's posture. To translate concerns into guidelines, a two hour workshop was held with nine design engineers. Ergonomists presented the concerns with pictures indicating the problem to be solved. Engineers assisted in developing the language for the guidelines that would help minimize the concern.

\section{SOLUTION RESULTS AND DISCUSSION}

The finalized fixture development process is shown in Figure 1. The four boxes highlighted in yellow specify that the Ergonomist is a member of the team (with quality, product focused engineers, designers, etc.) who reviews and ensures that requirements are met at the following four stages of the design process: 1 ) fixture 
Association of Canadian Ergonomists Annual Conference, Halifax, 2012

design kick-off meeting to clarify design requirements and initiate the DFMEA (design failure modes effects analysis); 2) the fixture design review; 3 ) the production tool design sign-off; and 4) lessons learned.

The twelve ergonomic guidelines resulting from the workshop with the engineers were incorporated into the design requirements with photos showing "good" and "poor" design examples for each guideline. For example:

- Flexibility and adjustability for viewing angle, access, and handedness, eg. Where possible, a fixture rotates, changes angle, tilts

- Physical access (space) for hands or tools and clear visual viewing angle

- Prevent blind assembly

- Eliminate obstructions in front of working area for ease of access e.g. knob position

- Standardized light colors e.g. yellow - in process, green - complete, red - fault

- Locate lights as close to hand location as possible

- Design should not rely on operator for positioning

- Ensure operations do not cause change in positioning of part i.e. that it needs stabilization by person

- Avoid having to hold with 2nd hand while loading

Since the Ergonomist is part of the fixture design process, and lessons learned are integral to the process, there are also opportunities to evaluate and improve the guidelines on an ongoing basis.

\section{CONCLUSIONS}

Intentionally, or not, HF standards are often ignored by design engineers. In this initiative, through participation, designers have gained an increased understanding of HF concerns through development of both the customized criteria and the design process incorporating a HF specialist. This participatory approach to developing and applying ergonomic design-for-fixture guidelines has the potential for improving assembly ergonomics and quality across thousands of workers.

\section{REFERENCES}

1. Broberg O. 2007. Integrating ergonomics into engineering: Empirical evidence and implications for the ergonomists. HF and Ergo in Mfg 17(4):353-366.

2, Jensen PL. 2002. Human factors and ergonomics in the planning of production. Int J Ind Ergo 29:121-131. 3. Munck-Ulfsfalt U, Falck, et al. 2003. Corporate ergonomics programme at Volvo car corporation. App Ergo 34:17-22.

4. Neumann WP, Ekman, M., Winkel, J. 2009. Integrating ergonomics into production system development - the Volvo Powertrain case. Appl Ergo 40:527-537.

5. Skepper N, Straker, L., Pollock, C. 2000. A case study of the use of ergonomics information in a heavy engineering design process. Int J Ind Ergo 26:425-435.

6. Wulff IA, Westgaard, R.H., Rasmussen, B. 1999. Ergonomic criteria in large-scale engineering design - II Evaluating and applying requirements in the real world of design. App Ergo 30:207-221.

\section{ACKNOWLEDGEMENTS}

The authors are grateful for the funding supplied by the Workplace Safety Insurance Board of Ontario

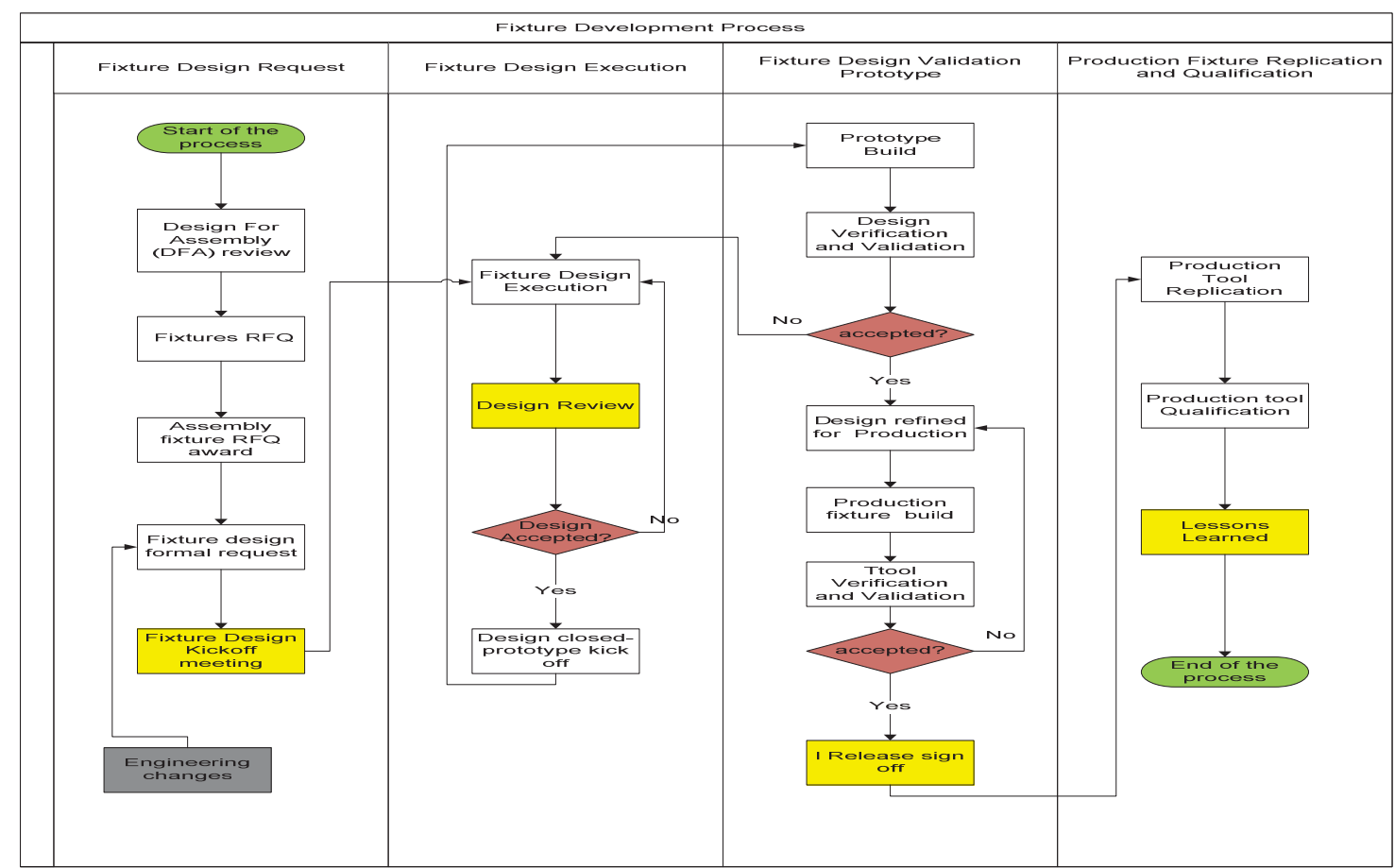

Figure 1. Fixture development process with yellow boxes indicating ergonomics requirements must be met and signed-off. 